\title{
SCREENING OF THE EFFECT OF GROUND WATER QUALITY ON THE STABILITY OF NORFLOXACIN AND DOXYCYCLINE IN DRINKING WATER OF POULTRY
}

\author{
SABER KOTB ${ }^{1}$; MOUSTAFA AHMED ${ }^{1}$; DALIA HASSAN ${ }^{1}$ and ESRAA SOLTAN ${ }^{2}$ \\ ${ }^{1}$ Animal and Poultry Hygiene and Environmental Sanitation Department, Faculty of Veterinary Medicine, \\ Assiut University, Egypt. http://www.aun.edu.eg/ \\ ${ }^{2}$ Animal Health Research Institute, Sohag, Egypt.
}

Received: 30 June 2019; Accepted: 21 July 2019

\begin{abstract}
This study was conducted to clarify the possible effects of ground water characteristics of the New ValleyEgypt, on the concentrations of both norfloxacin and doxycycline "in- vitro". Thirty two ground water samples (pooled samples) were collected and examined for their water quality parameters and heavy metals concentrations $\left(\mathrm{pH}\right.$, chloride $\left(\mathrm{Cl}^{-}\right)$, calcium $\left(\mathrm{Ca}^{+}\right)$, magnesium $\left(\mathrm{Mg}^{+}\right)$, sodium $\left(\mathrm{Na}^{+}\right)$, total hardness, electrical conductivity (EC), total dissolved solids (TDS), iron (Fe), copper $(\mathrm{Cu})$, zinc $(\mathrm{Zn})$ and nickel (Ni). Therapeutic doses of both norfloxacin and doxycycline were added separately to the ground-water samples and were left for different contact times. Results showed that norfloxacin concentrations significantly decreased with increasing the time of contact till 3 hours while, doxycycline showed a non-significant decrease which increased with increasing the contact time to 8 hours. Each of TDS, EC, $\mathrm{Mg}^{+2}, \mathrm{Na}^{+}, \mathrm{Cl}^{-}$and $\mathrm{Fe}^{+2}$ showed significant positive correlations with the decreasing percent of norfloxacin while only $\mathrm{Ca}^{+2}$ ions concentration showed a significant negative correlation with the decreasing percent of doxycycline.
\end{abstract}

Key words: Groud-water- water quality, norfloxacin, doxycycline, poultry, heavy metals.

\section{INTRODUCTION}

Poultry is one of the most widespread food industries worldwide where chicken is the most commonly farmed species. A large multiplicity of antibiotics are used to raise up poultry in most countries (Sahoo et al., 2010; Landers et al., 2012 and Boamah et al., 2016). The main cause for adding antimicrobials in food-producing animals include prevention and control infections, promotion of growth and production improvement (Castanon et al., 2007 and Mathew et al., 2009). Both fluoroquinolones (FQs) and tetracyclines (TC) are among the most commonly used antibiotics in veterinary medicine in the world especially in poultry farms (Lindberg et al., 2004).

Fluoroquinolones are broad-spectrum antibacterial agents with potent antibacterial activity against gram-positive and gram-negative bacteria (Chierentin and Salgado, 2015). Norfloxacin is rapidly bactericidal that it might have a great potential for treating common infections such as

Corresponding author: Dr. Dalia Hassan

E-mail address: Daliamoh.hassan@gmail.com

Present address: Animal and Poultry Hygiene and Environmental Sanitation Department, Faculty of Veterinary Medicine, Assiut University. Egypt. http://www.aun.edu.eg/ mycoplasmosis, colibacillosis and pasteurellosis in chickens, turkeys and geese (Gulkarov and Ziv, 1994). Tetracyclines exhibit their activity against a wide range of gram-positive and gram-negative bacteria, chlamydia, mycoplasmas, rickettsia and protozoan parasites (Roberts, 1996). In veterinary medicine, tetracyclines have been extensively used in the therapy of animal and poultry infections, prophylactic purposes and growth promotion (Levy, 1992).

A huge number of such antimicrobials that used in poultry production are reflected to be crucial in human medicine (WHO 2010 and WHO 2017). The undiscriminating use of such essential antimicrobials in animal production is prospective to hasten the development of antibiotic resistance in pathogens. This would lead to therapy failures, financial losses and could act as a source of gene pool for transmission to humans. Moreover, there are human health concerns about the existence of antibiotic residues in animal meat (Darwish et al., 2013 and Aalipour et al., 2013), eggs (Goetting et al., 2011) and other edible animal products (Mehdizadeh et al., 2010 and Addo et al., 2011).

In recent years, enough confirmation highlighting the antimicrobial resistance from animals as a contributing factor for the inclusive burden of antimicrobial resistance and each of the extra 
unjustified overuse of antibiotics or the use of subtherapeutic doses of antibiotics (Mathew et al., 2007). Water that used as a substrate for antibiotic medication is a one of the important causes that may negatively affect a drug concentration in blood plasma of the treated birds. Low water quality was proven to decline antibiotics absorption" in-vivo" presenting sub-therapeutic doses than the required ones inside the animal bodies (Sumano et al., 2004 and Kołodyńska et al., 2012). Nevertheless, there are very scarce studies concerned with the possible invitro effect of water quality and characteristics on different antibiotic's solubility, stability and bioavailability.

\section{MATERIALS AND METHODS}

1- Area of study
This study was conducted in Al-Dakhla Oasis - the New Valley, Egypt. Thirty two ground water samples were collected from different wells were situated around different poultry farms that depended mainly on ground-water for drinking of birds. The New Valley Governorate is situated 350 $\mathrm{Km}$ far from the Nile River, on the south western part of Egypt western desert. The sampling locations were given in (Fig. 1).

\section{2- Sampling}

Water collection and sampling were done according to APHA, 2005 in a representative amounts where 1L capacity dark glass bottles were used for sample's collection. All glass bottles were washed carefully with a final rinse with distilled water. All used bottles were sterilized before sampling. Groundwater samples were labeled and transported to the laboratory in an ice box for further analyses.

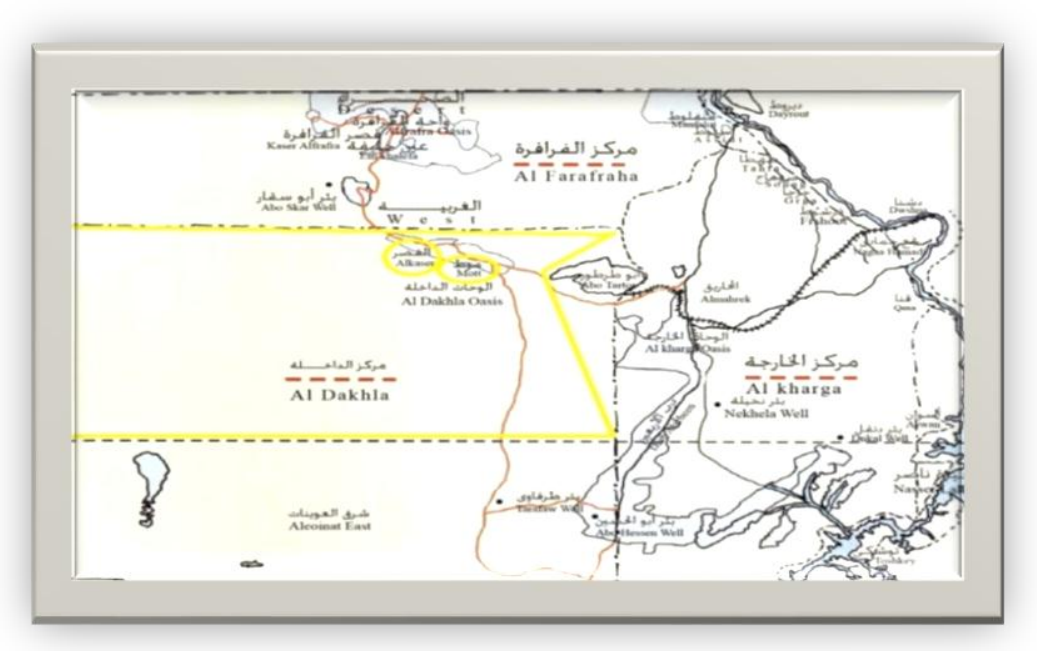

Figure 1: Google map showing the localities of the sampling sites

\section{3- Water analysis}

Collected ground-water samples were subjected to multiple analytical processes including the estimation of some of water quality parameters, heavy metals concentrations and antibiotic residues.

\section{3-i Estimation of water quality parameters}

Including the estimation of several chemical water characteristics as water $\mathrm{pH}$, electrical conductivity (EC), some free ions including: chloride $\left(\mathrm{Cl}^{-}\right)$, calcium ions $\left(\mathrm{Ca}^{+2}\right)$, magnesium ions $\left(\mathrm{Mg}^{+2}\right)$ sodium ions $\left(\mathrm{Na}^{+}\right)$and some of water complex molecules including: total hardness (T.H) and total dissolved solids (TDS).

Values of $\mathrm{pH}$ were estimated by using $\mathrm{pH}$ meter model JWNWAY 3505 (Eneji et al., 2012). Electrical conductivity was estimated by conductivity meter (HI 9835- Italy). Total water hardness and total dissolved solids were estimated by using Lovibond Microprocessor Multi-direct Photometer- Germany. The analysis was conducted at Dept. of Animal Hygiene, Faculty of Veterinary Medicine, Assiut University. Chloride ions $\left(\mathrm{Cl}^{-}\right)$, Calcium ions $\left(\mathrm{Ca}^{+2}\right)$, magnesium ions $\left(\mathrm{Mg}^{+2}\right)$, sodium ions $\left(\mathrm{Na}^{+}\right)$concentrations were estimated by Flame Photometer Model M 360 according to (Costanzo and Windhager, 1980) in laboratories of the Soil and Water Department, Faculty of Agriculture, Assiut University, Egypt.

\section{3-ii Estimation of heavy metals concentrations}

Water samples were subjected to cold and hot digestion processes using a mixture of $\mathrm{HNO}_{3}$ : $\mathrm{HCLO}_{3}(4: 1 \mathrm{v} / \mathrm{v})$ according to Chau and Lum, 1979 for the estimation of iron $(\mathrm{Fe})$, copper $(\mathrm{Cu})$, zinc (Zn) and nickel (Ni) A blank was prepared. calibration standards for all tested metals were prepared by serial dilution of concentrated stock solutions of $1000 \mathrm{mg} / \mathrm{L}$ and blank sample (de- 
ionized water) were analyzed for the digested samples according to Tewari and Singh, 2000 by using Flame Atomic Absorption Spectrophotometer (Perkin-Elmer Atomic Absorption Spectrophotometer model A Analyst 400). Analysis was done in triplicate and average values were calculated. Concentrations of the four analyzed heavy metals were calculated according to (Horwitz et al., 2000).

3-iii Estimation of antibiotics residues in groundwater samples

Both norfloxacin (fluoroquinolones member) and doxycycline (tetracyclines member) residues in the all tested drinking water samples were estimated using Thin Layer Chromatography (TLC) in the Drug Researches Center, Assiut University according to Thangadurai et al. (2002).

\section{4- The experimental work:}

Norfloxacin 30\% (1200 mg/L) and doxycycline $20 \%$ $(300 \mathrm{mg} / \mathrm{L})$ Pfizer Egypt-Pharma were used in the experiment. In the laboratory and in the same light condition and indoor temperature the therapeutic doses of both norfloxacin and doxycycline were separately added to the all tested water samples. Samples were left for 1 hour, 3 hours, 5 hours and 8 hours where, after each contact time the antibiotic concentration was re-evaluated. Control samples of both norfloxacin and doxycycline (which included the therapeutic dose of norfloxacin and doxycycline separately was dissolved in bi-distilled water) and measured in the same conditions after each separate contact time. All samples were estimated in triplicates. The antibiotic estimation was done by using the Thin Layer Chromatography (TLC) in the Drug Researches Center, at Assiut University according to Thangadurai et al. (2002).

Technique used in Thin Layer Chromatography (TLC) for estimation of norfloxacin and doxycycline concentrations in all tested drinking water samples:

This technique was used for both norfloxacin and doxycycline estimation either as a residue in the tested water samples or for measuring the therapeutic concentration after each contact time. Analysis was performed with several mobile phases for the individual identification of both fluoroquinolone and tetracycline (British Pharmacopoeia, 2012).

\section{i - Instrument specification:}

- CAMAG TLC scanner IV for scanning by absorbance and fluorescence, wavelength 190 900nm complete with deuterium lamp, tungsten halogen lamp and mercury vapor lamp

- CAMAG Linomat 5, 230V, for sample application spot or band wise in quantitative and qualitative TLC. $100 \mu \mathrm{L}$ Hamilton glass sample syringe for dosing of samples., Wincats version: 1.4.10, Scanning speed: $20 \mathrm{~mm} / \mathrm{s}$, Data resolution: $100 \mu \mathrm{m} / \mathrm{step}$

- CAMAG Twin trough chamber for plates $20 \times 10$ and $10 \times 10 \mathrm{~cm}$ with stainless steel lid.

\section{ii- Chromatographic preparation for antibiotics estimations: \\ The selected mobile phase system (Methanol:} Ammonia) was poured into the TLC tank lined with thick filter paper to help saturation of the tank. The tank was then covered with its lid and pre-saturated with the mobile phase system vapors for at least 30 minutes at room temperature $\left(25^{\circ} \mathrm{C}\right)$ before use. Size of the plate used for the analysis is $20 \times 10 \mathrm{~cm}$. The samples were spotted in the form of bands $4 \mathrm{~mm}$ length with CAMAG microliter syringe on the TLC plate using CAMAG Linomat 5. The slit dimensions were kept $4 \mathrm{~mm} \times 0.35 \mathrm{~mm}$, in the CAMAG scanner in reflectance absorbance mode.

The source of radiation was deuterium lamp emitting radiation in the range $190-900 \mathrm{~nm}$. Scanning of the plate was carried out twice, at 280 and $378 \mathrm{~nm}$ for norfloxacine and doxycycline respectively.

\section{Statistical analysis:}

All data was analyzed using IBM SPSS Statistics for Windows version 25 (Field, 2013). Quantitative data were expressed as means \pm standard deviation. Qualitative data were expressed as number and percentage. The nonparametric Mann-Whitney test, Friedman One-Way ANOVA test and Spearman's correlation were used for data which wasn't normally distributed. Independent Samples T test was used for normally distributed data. A 5\% level was chosen as a level of significance. 


\section{RESULTS}

Table 1: The estimated values of water quality parameters and heavy metals concentrations in the tested groundwater samples.

\begin{tabular}{|c|c|c|c|}
\hline Water Parameters\& Heavy metals & Minimum & Maximum & Mean \pm S.D. \\
\hline pH & 5.00 & 6.00 & $5.6 \pm 0.82$ \\
\hline $\begin{array}{c}\text { Total dissolved solids } \\
\text { (T.D.S) }(\mathrm{mg} / \mathrm{L})\end{array}$ & 523.79 & 1987.53 & $1597.60 \pm 501.64$ \\
\hline $\begin{array}{l}\text { Electrical conductivity } \\
(\mathrm{EC})(\mathrm{dc} / \mathrm{m})\end{array}$ & 0.85 & 3.55 & $2.49 \pm 0.78$ \\
\hline $\begin{array}{c}\text { Total Hardness } \\
\text { (T.H) }(\mathrm{mg} / \mathrm{L})\end{array}$ & 281 & 531 & $459.37 \pm 83.38$ \\
\hline $\begin{array}{l}\text { Calcium ions } \\
\left(\mathrm{Ca}^{+2}\right)(\mathrm{mg} / \mathrm{L})\end{array}$ & 80 & 120 & $98.75 \pm 18.85$ \\
\hline $\begin{array}{l}\text { Magnesium ions } \\
\left(\mathrm{Mg}^{+2}\right)(\mathrm{mg} / \mathrm{L})\end{array}$ & 195 & 420 & $360.62 \pm 74.61$ \\
\hline $\begin{array}{l}\text { Sodium ions } \\
\left(\mathrm{Na}^{+}\right)(\mathrm{mg} / \mathrm{L})\end{array}$ & 72.90 & 290 & $194.11 \pm 70.99$ \\
\hline $\begin{array}{l}\text { Chloride ions } \\
\left(\mathrm{Cl}^{-}\right)(\mathrm{mg} / \mathrm{L})\end{array}$ & 177.50 & 461.50 & $386.05 \pm 106.40$ \\
\hline $\begin{array}{c}\text { Nickel } \\
(\mathrm{Ni})(\mathrm{mg} / \mathrm{L})\end{array}$ & 0.0003 & 0.558 & $0.327 \pm 0.175$ \\
\hline $\begin{array}{c}\text { Iron } \\
(\mathrm{Fe})(\mathrm{mg} / \mathrm{L})\end{array}$ & 30.08 & 533.94 & $338.60 \pm 174.04$ \\
\hline $\begin{array}{c}\text { Copper } \\
(\mathrm{Cu})(\mathrm{mg} / \mathrm{L})\end{array}$ & 0.146 & 1.137 & $0.396 \pm 0.311$ \\
\hline $\begin{array}{c}\text { Zinc } \\
(\mathrm{Zn})(\mathrm{mg} / \mathrm{L})\end{array}$ & 4.88 & 13.95 & $10.21 \pm 3.33$ \\
\hline Norfloxacin residue & & $00 \pm 00$ & \\
\hline Doxycycline residue & & $00 \pm 00$ & \\
\hline
\end{tabular}

Table 2: Statistical analysis of the impact of ground water on the therapeutic concentration of Norfloxacin and Doxycycline after different contact times.

\begin{tabular}{|c|c|c|c|c|c|c|c|c|c|}
\hline \multirow{3}{*}{$\begin{array}{c}\text { Type of } \\
\text { Antibiotics }\end{array}$} & \multirow{3}{*}{$\begin{array}{c}\text { Control } \\
\text { (Therapeutic } \\
\text { dose) }\end{array}$} & \multicolumn{8}{|c|}{ Contact time / Decreasing \% } \\
\hline & & \multicolumn{2}{|c|}{ after1 hour } & \multicolumn{2}{|c|}{ after 3 hours } & \multicolumn{2}{|c|}{ after 5 hours } & \multicolumn{2}{|c|}{ after 8 hours } \\
\hline & & $\begin{array}{c}\text { Mean } \pm \\
\text { S.D. }\end{array}$ & $\begin{array}{c}\text { Decreasing } \\
\%\end{array}$ & $\begin{array}{l}\text { Mean } \\
\pm \text { S.D. }\end{array}$ & $\begin{array}{c}\text { Decreasing } \\
\%\end{array}$ & $\begin{array}{c}\text { Mean } \pm \\
\text { S.D. }\end{array}$ & $\begin{array}{c}\text { Decreasing } \\
\%\end{array}$ & $\begin{array}{l}\text { Mean } \\
\pm \text { S.D. }\end{array}$ & $\begin{array}{c}\text { Decreasing } \\
\%\end{array}$ \\
\hline \multirow[t]{2}{*}{ Norfloxacin } & $1200 \pm 0$ & $\begin{array}{l}1162.5 \\
\pm 1.05 \\
\end{array}$ & $3.13 \%$ & $\begin{array}{c}1121.25 \\
\pm 1.98 \\
\end{array}$ & $6.56 \%$ & $\begin{array}{c}1121.25 \\
\pm 1.98 \\
\end{array}$ & $6.56 \%$ & $\begin{array}{c}1121.25 \\
\pm 1.98 \\
\end{array}$ & $6.56 \%$ \\
\hline & P-value & \multicolumn{2}{|r|}{0.176} & \multicolumn{2}{|c|}{ 0.038* } & \multicolumn{2}{|c|}{ 0.038* } & \multicolumn{2}{|c|}{ 0.038* } \\
\hline \multirow[t]{2}{*}{ Doxycycline } & $300 \pm 0$ & $\begin{array}{r}297.5 \\
\pm 0.78\end{array}$ & $0.83 \%$ & $\begin{array}{l}274.7 \\
\pm 0.98\end{array}$ & $8.42 \%$ & $\begin{array}{r}268.7 \\
\pm 1.03\end{array}$ & $10.42 \%$ & $\begin{array}{r}259.2 \\
\pm 1.06\end{array}$ & $13.58 \%$ \\
\hline & P-value & \multicolumn{2}{|r|}{0.149} & \multicolumn{2}{|r|}{0.144} & \multicolumn{2}{|r|}{0.129} & \multicolumn{2}{|r|}{0.110} \\
\hline
\end{tabular}

\footnotetext{
$* \mathrm{P}$ - value $<0.05$ is statistically significant
} 
Table 3: Statistical correlations between water parameters\& heavy metals concentrations and the decreasing $\%$ of both Norfloxacin and Doxycycline.

\begin{tabular}{|c|c|c|c|c|}
\hline \multirow{2}{*}{ Water Parameter } & \multicolumn{2}{|c|}{ Norfloxacin } & \multicolumn{2}{|c|}{ Doxycycline } \\
\hline & $\mathbf{r}$ & P-value & $\mathbf{r}$ & P-value \\
\hline pH & 0.037 & 0.931 & 0.146 & 0.729 \\
\hline $\begin{array}{c}\text { Total Dissolved } \\
\text { Solids } \\
(\mathrm{mg} / \mathrm{L}) \\
\end{array}$ & 0.712 & $0.048 *$ & 0.488 & 0.220 \\
\hline $\begin{array}{c}\text { Electrical } \\
\text { Conductivity } \\
(\mathbf{d c} / \mathbf{m})\end{array}$ & 0.712 & $0.048 *$ & 0.488 & 0.220 \\
\hline $\begin{array}{c}\text { Water Hardness } \\
(\mathrm{mg} / \mathrm{L})\end{array}$ & 0.621 & 0.100 & -0.078 & 0.854 \\
\hline $\begin{array}{c}\text { Calcium ions }\left(\mathrm{Ca}^{+2}\right) \\
(\mathrm{mg} / \mathrm{L})\end{array}$ & -0.052 & 0.903 & -0.718 & $0.045 *$ \\
\hline $\begin{array}{c}\text { Magnesium ions } \\
\left(\mathrm{Mg}^{+2}\right) \\
(\mathrm{mg} / \mathrm{L}) \\
\end{array}$ & 0.921 & $0.001 *$ & 0.342 & 0.408 \\
\hline $\begin{array}{c}\text { Sodium ions }\left(\mathrm{Na}^{+}\right) \\
(\mathrm{mg} / \mathrm{L})\end{array}$ & 0.951 & $0.000 *$ & 0.344 & 0.405 \\
\hline $\begin{array}{c}\begin{array}{c}\text { Chloride }\left(\mathrm{Cl}^{-}\right) \\
(\mathrm{mg} / \mathrm{L})\end{array} \\
\end{array}$ & 0.544 & $0.001 *$ & 0.226 & 0.590 \\
\hline $\begin{array}{c}\text { Nickle(Ni) } \\
(\mathrm{mg} / \mathrm{L})\end{array}$ & -0.466 & 0.244 & -0.342 & 0.408 \\
\hline $\begin{array}{c}\operatorname{Iron}(\mathbf{F e}) \\
(\mathrm{mg} / \mathrm{L}) \\
\end{array}$ & 0.773 & $0.024 *$ & 0.098 & 0.818 \\
\hline $\begin{array}{c}\text { Copper }(\mathrm{Cu}) \\
(\mathrm{mg} / \mathrm{L})\end{array}$ & 0.037 & 0.931 & -0.123 & 0.772 \\
\hline $\begin{array}{c}\text { Zinc }(\mathrm{Zn}) \\
(\mathrm{mg} / \mathrm{L}) \\
\end{array}$ & 0.503 & 0.204 & 0.537 & 0.170 \\
\hline
\end{tabular}

* P- value $<0.05$ is statistically significant

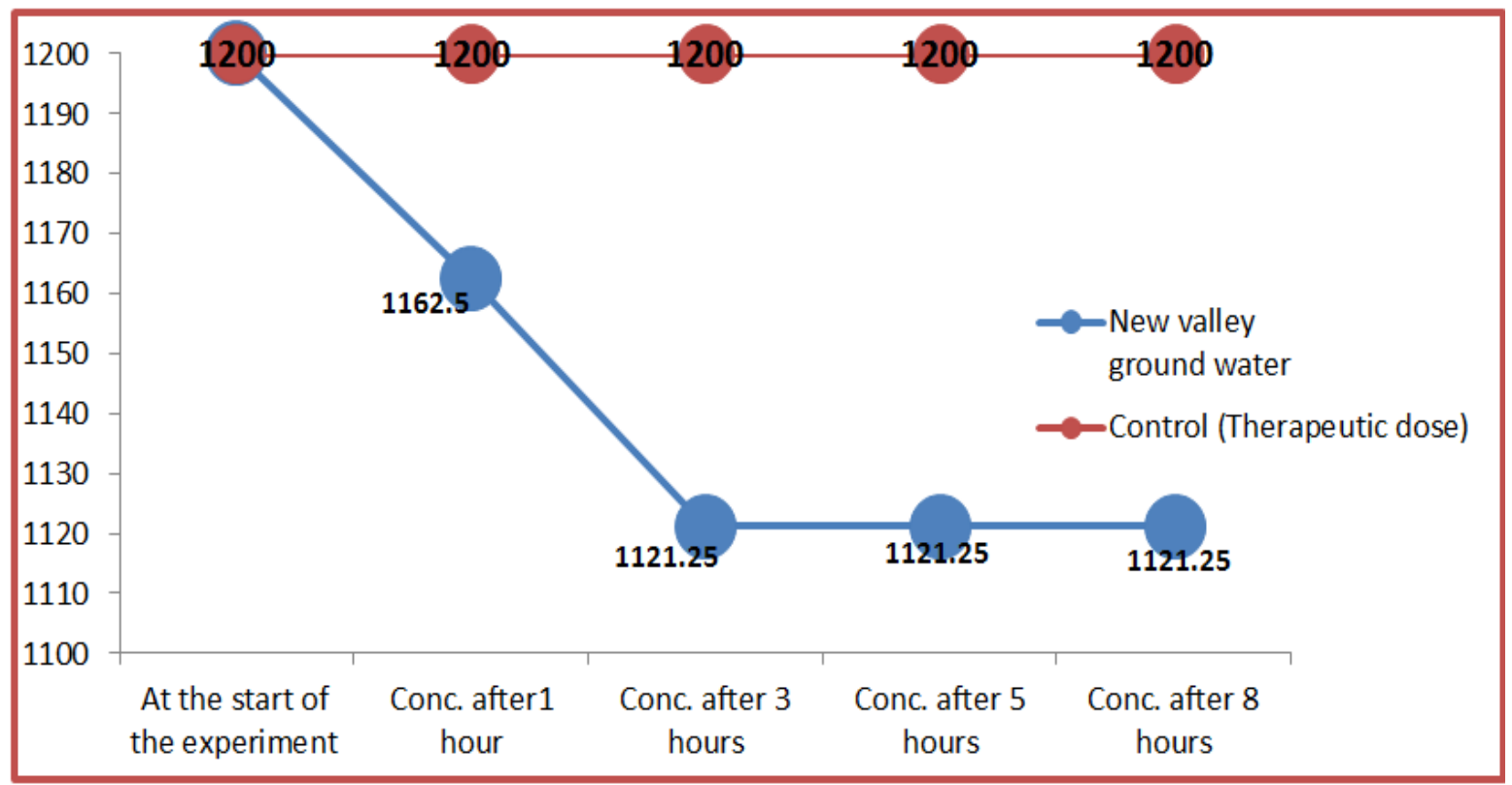

Figure 2: Norfloxacin therapeutic concentrations in groundwater samples after different contact times. 


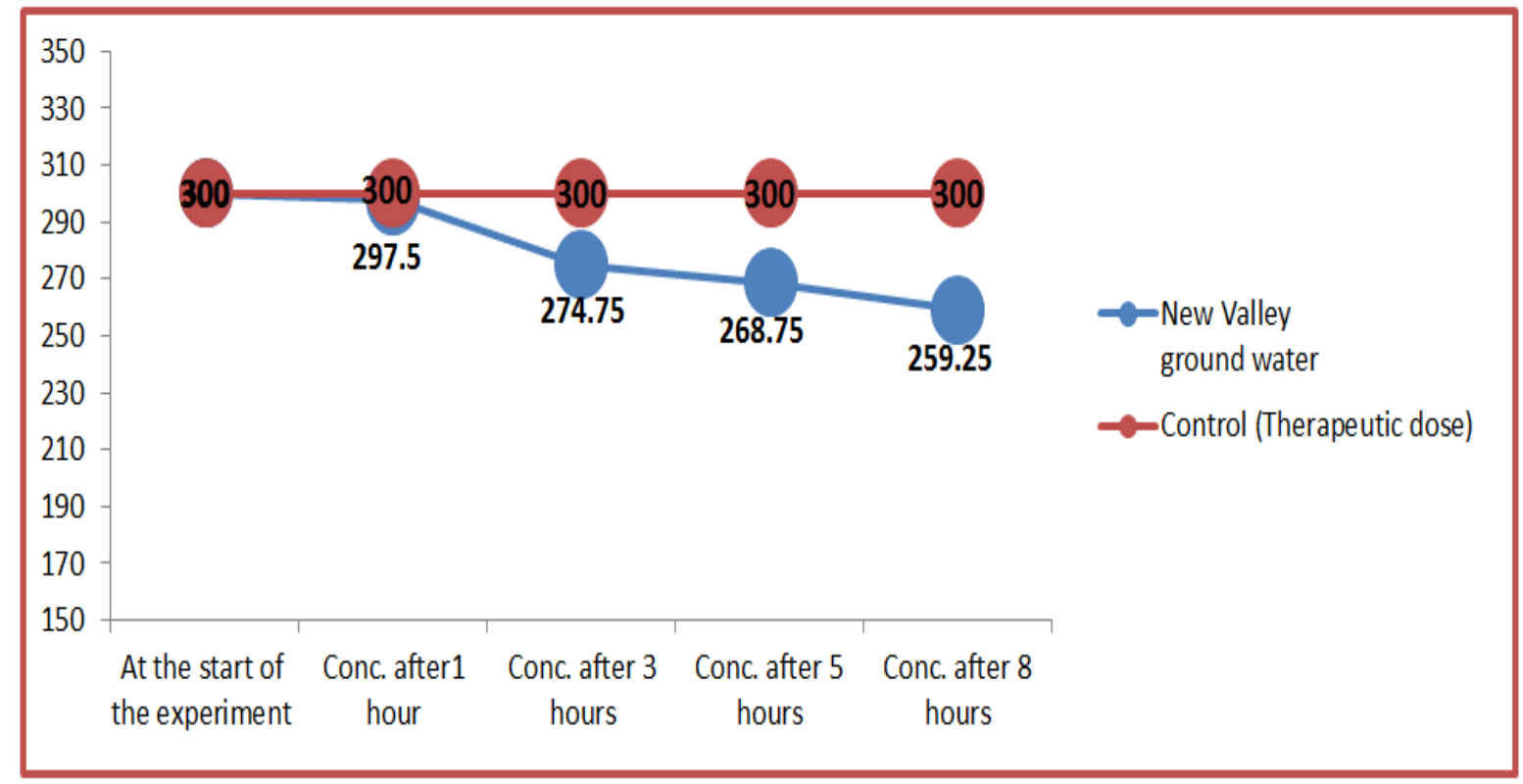

Figure 3: Doxycycline therapeutic concentrations in ground water samples after different contact times.

The estimated values of water quality parameters and heavy metals concentrations in the analyzed ground water samples were summarized in (table 1). It was clear that all $\mathrm{pH}$ values were recorded in an acidic range while all the other estimated water parameters showed variable degrees and concentrations. Iron among the analyzed heavy metals showed the highest concentrations while Nickel was recorded in the lowest concentrations. Residues of both norfloxacin and doxycycline were not detected in any of the analyzed groundwater samples.

Re-measuring of the therapeutic doses of the tested antibiotic concentrations in the examined water samples after each contact time was shown in (table 2). Norfloxacin concentrations gradually declined from the $1^{\text {st }}$ till the $3^{\text {rd }}$ hour of exposure time. No further decrease in norfloxacin concentration was recorded and it remained in a stable value after the $5^{\text {th }}$ and $8^{\text {th }}$ hour of contact time. The decreasing percent after the $1^{\text {st }}$ hour $(3.13 \%)$ was nonsignificantly different from the control value while, a significant difference $(\mathrm{P}<0.05)$ was recorded after the $3^{\text {rd }}$ hour of contact time $(6.65 \%)$. The control sample of norfloxacin did not show any decrease in its therapeutic concentration after all tested contact times (fig. 2).

Doxycycline showed relatively dissimilar manner from norfloxacin where, doxycycline concentration recorded a decrease after the $1^{\text {st }}$ hour, with subsequent decreasing in its concentrations at the $3^{\text {rd }}, 5^{\text {th }}$ and $8^{\text {th }}$ hours of contact time $(0.83 \%, 8.42 \%$, $10.42 \%$ and $13.58 \%$ ), respectively. After eight hours of contact time no an additional decrease in doxycycline concentration was recorded. None of the documented decreasing values of doxycycline concentrations was significantly different from the control value. The control samples of doxycycline did not show any decrease in its therapeutic concentration after all tested contact times (fig. 3).

The statistical correlation between water characteristics, heavy metals values and both norfloxacin and doxycycline were shown in (table 3). TDS, EC, $\mathrm{Mg}^{+2}, \mathrm{Na}^{+}, \mathrm{Cl}^{-}$and iron showed significant positive correlation with the decreasing percent of norfloxacin. On the other hand, only $\mathrm{Ca}^{+2}$ ions concentration showed a significant negative correlation with the decreasing percent of doxycycline concentration.

\section{DISCUSSION}

Comparing the obtained results of the estimated water quality parameters and heavy metals concentrations with the listed permissible limits of WHO, 2011, it was found that the mean values of $\mathrm{Ca}^{+2}$ and $\mathrm{Na}^{+}$were within the permissible concentrations $(200 \mathrm{mg} / \mathrm{L})$ while both $\mathrm{Mg}^{+2}$ and $\mathrm{Cl}^{-}$ ions concentrations crossed the permissible limits (125 mg/L, $250 \mathrm{mg} / \mathrm{L})$, respectively. All recorded $\mathrm{pH}$ values were lower than the optimum limits (6.58.5). Concerning heavy metals concentrations it was found that only copper was recorded within the permissible range $(2 \mathrm{mg} / \mathrm{L})$. Iron values were vastly higher than the permissible limits $(0.3 \mathrm{mg} / \mathrm{L})$. In the same context both nickel and zinc exceeded the permissible limits $(0.07 \mathrm{mg} / \mathrm{L}$ and $3 \mathrm{mg} / \mathrm{L})$, respectively. 
It was clear that application of norfloxacin and doxycycline in the ground water samples resulted in a drop in their therapeutic doses. In the same time and condition of the experimental work, the control samples of both norfloxacin and doxycycline did not show any decrease in their initial therapeutic concentrations. This finding ascertained that water characteristics definitely affected on the antibiotic's stability in water. This finding was in agreement with Lam et al. (2003); McIntyre and Lipman (2007).

Another stressing point is that the ground water characteristics did not affect the two tested antibiotics in the same degree and manner. Increasing the contact time of doxycycline in ground-water samples was parallel to its gradual non-significant decrease in its concentration. Although norfloxacin exhibited a limited effect by increasing the contact time which vanished after the $3^{\text {rd }}$ hour of contact time, its declining in value was significantly different from the therapeutic control value of norfloxacin.

Impacts of water quality characteristics on both norflxacin and doxycycline therapeutic concentrations "in-vitro"

From the given results, it was obvious that, free ions concentrations, including $\mathrm{Mg}^{+}, \mathrm{Na}^{+}$and $\mathrm{Cl}^{-}$showed strong positive correlations with the decreasing values of norfloxacin. Moreover, another two related free ions parameters including TDS and EC showed the same effect. This mainly explained via the finding of Bečić et al., 2014 who confirmed that fluoroquinolones had a very strong tendency to form complexes with ions. This finding concerning the possible effect of both $\mathrm{Cl}^{-}$and TDS on fluoroquinolones member degradation in water was in agreement with Lam et al. (2003), Fisher et al. (2006) and Ge et al. (2010).

Concerning heavy metals values only iron (Fe) showed a significant positive correlation with the decreasing percent of the therapeutic dose of norfloxacin in-vitro. This result was in agreement with Serafin and Stanczak (2009), who mentioned that norfloxacin reacted with iron at room temperature to form solid complexes.

Different outcome was obtained for doxycycline where, only $\mathrm{Ca}^{+2}$ concentration recorded a negative significant correlation with its declining percent. None of the other estimated water quality parameters (pH, TDS, TH, $\mathrm{Mg}^{+2}, \mathrm{Cl}^{-}, \mathrm{Na}^{+2}, \mathrm{Ec}$ ) showed any significant correlation with the decreasing values of doxycycline. The non-significant effect of the groundwater with an acidic nature on the decreasing percent of doxycycline concentrations was in agreement with (Marx, 2014) who found that there was no effect of the acidified water on the concentration of doxycycline after different contact times in- vitro.

Moreover, no significant correlations were recorded between all estimated heavy metals and doxycycline concentration. This result disagreed with Oka et al. (2000) who reported that tetracyclines tend to form strong complexes with copper and iron and Sunaric et al. (2009) who found that $\mathrm{Fe}^{+2}$ and $\mathrm{Zn}^{+2}$ ions had an ability to form stable complexes in aqueous solution with doxycycline and Andreu et al. (2016) who found that doxycycline had a potential interaction with the total content of nickel in different water samples.

\section{CONCLUSION}

This study concluded that ground-water caused a decrease in both norfloxacin and doxycycline concentrations after different contact times. Norfloxacin showed no further decrease after the $3^{\text {rd }}$ hour while doxycycline showed continuous insignificant decrease till the $8^{\text {th }}$ hour of contact time. The free ions concentrations were remarkably correlated with norfloxacin drop in concentrations while only $\mathrm{Ca}^{+2}$ ions were negatively correlated with doxycycline decreasing value "in- vitro". So, the process of adjusting the therapeutic dose of the administered antibiotic and the use of high quality water as a medium for bird medication is very important to avoid many subsequent problems including sub-therapeutic doses which result in drug resistance or failure of treating flocks by safe and effective types of antibiotics.

\section{ACKNOWLEDGMENTS}

This research was supported by department of Animal and Poultry Hygiene and Environmental Sanitation/ Faculty of Veterinary medicine, Assiut University, Assiut, Egypt. http://www.aun.edu.eg

\section{REFERENCES}

Addo, KK.; Mensah, GI.; Aning, KG.; Nartey, N.; Nipah, GK.; Bonsu, C.; Akyeh, ML. and Smits, HL. (2011): Microbiological quality and antibiotic residues in informally marketed raw cow milk within the coastal savannah zone of Ghana. Tropical Medicine and International Health.16: 227-232. https:// doi.org/10.1111/j.1365-3156.2010. 02666.x

Andreu, V.; Gimeno-García, E.; Pascual, J.A.; Vázquez-Roig, P. and Picó, Y. (2016): Presence of pharmaceuticals and heavy metals in the waters of a Mediterranean coastal wetland: Potential interactions and the influence of the environment. Science of the Total Environment J., 540, 278-286. https:// doi.org/10.1016/j.scitotenv.2015.08.007 
APHA (American Public health Association) (2005): Standard methods for the examination of water and waste water, $21 \mathrm{Ed}$., APHA, Inc. Washington D.C. https://www.worldcat.org/ title/standard-methods-for-the-examinationof-water-and-wastewater/oclc/156744115.

Boamah, VE.; Agyare, C.; Odoi, H. and Dalsgaard, A. (2016): Antibiotic practices and factors influencing the use of antibiotics in selected poultry farms in Ghana. Journal of Antimicrobial Agents. 2: 120. DOI:10.4172/ 2472-1212.1000120.

British Pharmacopoeia (2012): Formulated Preparations: Specific Monographs, Tetracycline Capsules. British Pharmacopoeia Commission, London, Volume III. https://www.pharmacopoeia. com/Catalogue/ProductDetails?productid $=10$ $\underline{00018792 \& \text { page }=1 \& \text { pageSize }=20 \& \text { searchTe }}$ $\mathrm{xt}=\&$ startsWith $=\mathrm{T}$

Castanon, JIR. (2007): History of the use of antibiotic as growth promoters in European poultry feeds. Poultry Science.86:2466-2471. DOI:10.3382/ps.2007-00249

Chau, Y.K. and Lum, S.C.K. (1979): Determination of Label and Strongly Bound Metals in Lake. Water Research J., 8, 383-388. https://doi. org/10.1016/0043-1354(74)90052-9

Chierentin, L. and Salgado, H. (2015): Review of Properties and Analytical Methods for the Determination of Norfloxacin.Article in Critical Reviews in Analytical Chemistry 46(1). https://doi.org/10.1080/ 10408347.2014.941456.

Costanzo, L.S. and Windhager, E.E. (1980): Effects of PTH, ADH, and cyclic AMP on distal tubular $\mathrm{Ca}$ and $\mathrm{Na}$ reabsorption. American Journal of Physiology-Renal Physiology, 239(5), 478-485. https://www. ncbi.nlm.nih.gov/pubmed/6249536

Darwish, WS.; Eldaly, EA.; El-Abbasy, MT.; Ikenaka, Y.; Nakayama, S. and Ishizuka, M. (2013): Antibiotic residues in food: The African scenario. Japanese Journal of Veterinary Research. 61:S13-S22. http://hdl.handle.net/2115/52350

Eneji, I.S.; Onuche, A.P. and Sha'ato, R. (2012): Spatial and temporal variation in water quality of River Benue, Nigeria. Journal of Environmental Protection, 3, 915. https://file. scirp.org/pdf/JEP20122800013_85580578. pdf

Field, A. (2013): Discovering statistics using IBM SPSS statistics. sage. https://uk.sagepub. com/en-gb/eur/discovering-statistics-usingibm-spss-statistics/book257672

Fisher, J.M.; Reese, J.G.; Pellechia, P.J.; Moeller, P.L. and Ferry, J.L. (2006): Role of Fe (III), phosphate, dissolved organic matter, and nitrate during the photodegradation of domoic acid in the marine environment. https://doi.org/10.1021/es051443b

Ge, L.; Chen, J.; Wei, X.; Zhang, S.; Qiao, X.; Cai, $X$. and Xie, $Q$. (2010): Aquatic photochemistry of fluoroquinolone antibiotics: kinetics, pathways, and multivariate effects of main water constituents. Environmental science \& technology J., 44(7), 2400-2405. https:// www.ncbi.nlm.nih.gov/pubmed/20205456

Goetting, V.; Lee, KA. and Tell, LA. (2011): Pharmacokinetics of veterinary drugs in laying hens and residues in eggs: A review of the literature. Journal of Veterinary Pharmacology and Therapy.34:521-556 DOI:10.1111/j.1365-2885.2011.01287.x

Gulkarov and Ziv (1994): Some pharmacokinetics features of norfloxacin nicotinate in turkey. In Abstract Proceeding. $6^{\text {th }} E A V P T$ International Congress, Edinburgh Ed. Less. P. pp 235. Blackwell Scientific Publication, Oxford. DOI: $10.1111 / \mathrm{jvp} .12004$

Horwitz, W.; Albert, R. and Deutsch, M.J. (2000): Guidelines for collaborative study of procedure to validate characteristics of a method of analysis. AOAC official methods of analysis. 17th Ed. appendix D, 1-11. www.aoac.org/aoac prod imis/.../3.5SMPR Guidelinev12.1.pdf

Kołodyńska, D.; Wnętrzak, R.; Leahy, J.J.; Hayes, M.H.B.; Kwapiński, $W$. and Hubicki, Z. (2012): Kinetic and adsorptive characterization of biochar in metal ions removal. Chemical Engineering Journal, 197, 295-305. DOI: 10.1016/j.cej.2012.05.025

Lam, M.W.; Tantuco, K. and Mabury, S.A. (2003): Photofate: A new approach in accounting for the contribution of indirect photolysis of pesticides and pharmaceuticals in surface waters. Environmental Science \& Technology J., 37(5), 899-907. https://doi. org/10.1021/es025902+

Landers, TF.; Cohen, B.; Wittum, TE. and Larson, EL. (2012): A review of antibiotic use in food animals. Perspective, policy, and potential. Public Health Reports. 2012; 127(1): 4-22. DOI: $10.1177 / 003335491212700103$

Levy, S.B. (1992): The antibiotic paradox: How miracle drugs are destroying the miracle. Plenum Publ. Corp., New York.

Lindberg, R.; Jarnheimer, P.A.; Olsen, B.; Johansson, M. and Tysklind, M. (2004): Determination of antibiotic substances in hospital sewage water using solid phase extraction and liquid chromatography/mass spectrometry and group analogue internal standards. Chemosphere J., 57(10), 14791488.

DOI:10.1016/j.chemosphere.2004.09.015

Marx, J.O.; Vudathala, D.; Murphy, L.; Rankin, S. and Hankenson, F.C. (2014): Antibiotic 
administration in the drinking water of mice. Journal of the American Association for Laboratory Animal Science, 53(3), 301-306. https://www.ncbi.nlm.nih.gov/pubmed/24827 573

Mathew, AG.; Cissell, R. and Liamthong, S. (2007): Antibiotic resistance in bacteria associated with animals: a United States perspective of livestock production. Foodborne Pathog., 4(2): 33-115. DOI:10.1089/fpd.2006.0066

Mathew, AG.; Liamthong, S. and Lin, J. (2009): Evidence of Int 1 transfer between Escherichia coli and Salmonella typhi. Food Biology. 6(8): 959-964. DOI: 10.1089/ pdf.2009.0263.

McIntyre, AR. and Lipman, NS. (2007): Amoxicillin-clavulanic acid and trimethoprim- sulfamethoxazole in rodent feed and water: effects of compounding on antibiotic stability. J Am Assoc Lab Anim Sci. $46(5):$ 26-32. https://www.ncbi. nlm.nih.gov/pubmed/17877324

Mehdizadeh, S.; Kazerani, HR. and Jamshidi, A. (2010): Screening of chloramphenicol residues in broiler chickens slaughtered in an industrial poultry abattoir in Mashhad, Iran. Iranian Journal of Veterinary Science and Technology.; 2: 25-32

Aalipour, F.; Mirlohi, M. and Jalali, M. (2013): Prevalence of antibiotic residues in commercial milk and its variation by season and thermal processing methods. International Journal of Environmental Health Engineering. 2:41. DOI: 10.4103/ 2277-9183.122429

Oka, H.; Ito, Y. and Matsumoto, H. (2000): Chromatographic analysis of tetracycline antibiotics in foods. Journal of Chromatography A, 882(1-2), 109-133. https: //doi.org/10.1016/S0021-9673(99)01316-3

Roberts, M.C. (1996): Tetracycline resistance determinants: mechanisms of action, regulation of expression, genetic mobility and distribution. FEMS Microbiology Reviews 19, 1-24. DOI: 10.1111/j.1574-6976. 1996.tb00251.x

Sahoo, KC.; Tamhankar, AJ.; Johansson, E. and Lundborg, CS. (2010): Antibiotic use, resistance development and environmental factors: A qualitative study among healthcare professionals in Orissa, India. Bi oMedical
Central Public Health. 10: 629. DOI: $\underline{10.1186 / 1471-2458-10-629}$

Serafin, A. and Stańczak, A. (2009): The complexes of metal ions with fluoroquinolones. Russian Journal of Coordination Chemistry, 35(2), 81-95.https://link.springer.com/content/ pdf/10.1134\%2FS1070328409020018.pdf

Sumano, L.H.; Gutierrez, O.L.; Aguilera, R.; Rosiles, M.R.; Bernard, B.M.J. and Gracia, M.J. (2004): Influence of hard water on the bioavailability of enrofloxacin in broilers. Poultry science J., 83(5), 726-731. https://watermark.silverchair.com/poultrysci8 3-0726.pdf

Sunaric, S.M.; Mitic, S.S.; Miletic, G.Z.; Pavlovic, A.N. and Naskovic-Djokic, D. (2009): Determination of doxycycline in pharmaceuticals based on its degradation by $\mathrm{Cu}(\mathrm{II}) / \mathrm{H} 2 \mathrm{O} 2$ reagent in aqueous solution. Journal of Analytical Chemistry, 64(3), 231237. https://link.springer.com/content/pdf/ 10.1134\%2FS1061934809030046.pdf

Tewari, P.K. and Singh, A.K. (2000): Thiosalicylic acid-immobilized Amberlite XAD-2: metal sorption behaviour and applications in estimation of metal ions by flame atomic absorption spectrometry. Analyst J, 125(12), 2350-2355. https://pubs.rsc.org/en/content/ articlepdf

Thangadurai, S.; Shukla, S.K. and Anjaneyulu, Y. (2002): Separation and detection of certain $\beta$ lactam and fluoroquinolone antibiotic drugs by thin layer chromatography. Analytical sciences J., 18(1), 97- 100.https://doi.org/ 10.2116/analsci.18.97

WHO (World Health Organization) (2010): WHO Model List of Essential Medicines. Geneva: 1-43.https://www.who.int/medicines/ publications/essentialmedicines/EML2015_8May-15.pdf

WHO (2011): Guideline for drinking water quality. Recommendations. $4^{\text {Ed }}$. ISBN. Geneva, World Health Organization. https:// apublica.org/wp-content/uploads/2014/03/ Guidelines-OMS-2011.pdf. SBN 978924 1548151.

WHO (World Health Organization) (2017): World Health Statistics: Monitoring Health for the Sustainable Development Goals. Geneva. https://apps.who.int/iris/handle/10665/ 255336. 


\section{فحص تأثير جودة المياه الجوفيه على ثبات النورفلوكساسين والدوكسيسيكلين فى ماء شرب الدواجن \\ صابر عبل المتبلّي قطب ، مصطفى محمد احد ، داليا محد على حسن ، اسراء رأفت سلطان}

E-mail: Daliamoh.hassan@gmail.com Assiut University web-site: www.aun.edu.eg

أجريت هذه الدر اسة بعد ازدياد الثكوى من المربيين و البيطريين من قلة فاعلية بعض المضينادات الحيويه المستخدمه عن طريق اذابتها

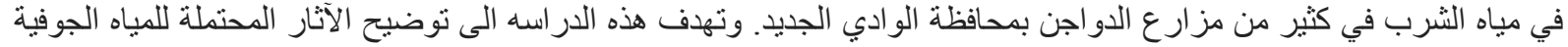

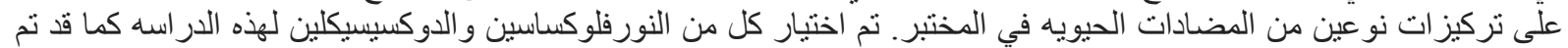

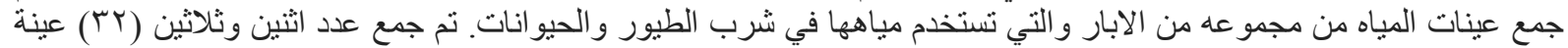

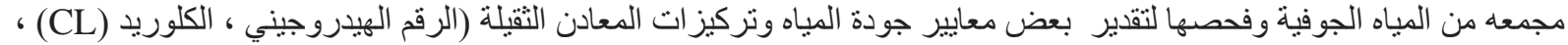

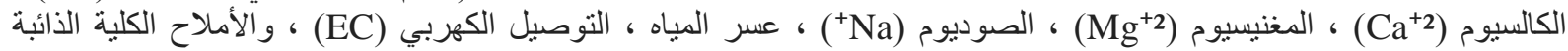

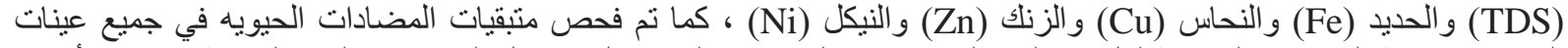

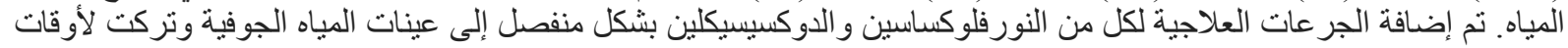

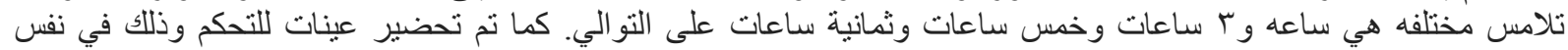

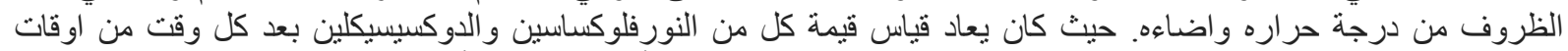

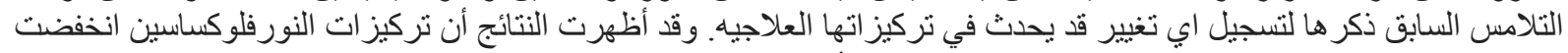

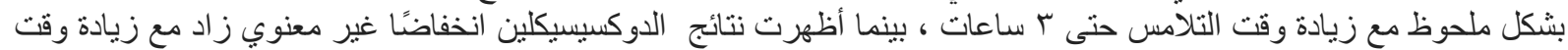

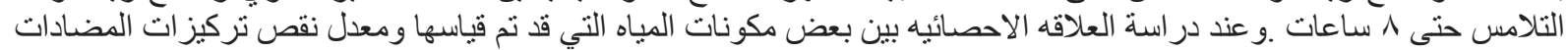

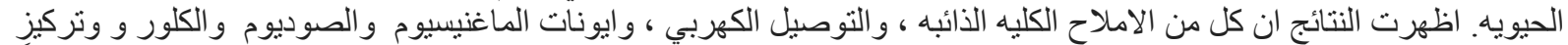

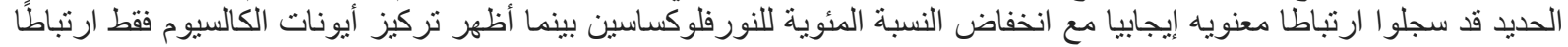

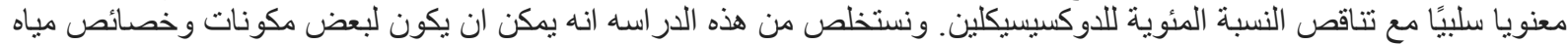

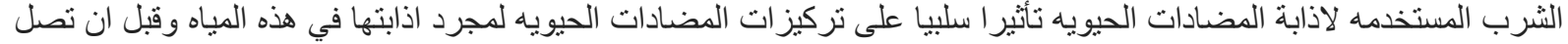

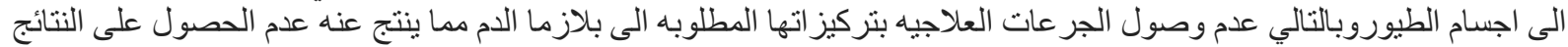
المرجوة من استخدام تلك الادوريه. 